\title{
Fluorescence assays for F-pili and their application
}

Correspondence

Philip Silverman

silvermanp@omrf.ouhsc.edu

Received 27 April 2005

Revised 8 June 2005

Accepted 12 June 2005

\author{
Katrin Daehnel,† Robin Harris, Lucinda Maddera and Philip Silverman \\ Program in Cell, Molecular, and Developmental Biology, Oklahoma Medical Research \\ Foundation, 825 NE 13th Street, Oklahoma City, OK 73104, USA
}

\begin{abstract}
Conjugative pili are extracellular filaments elaborated by Gram-negative bacteria expressing certain type IV secretion systems. They are required at the earliest stages of conjugal DNA transfer to establish specific and secure cell-cell contacts. Conjugative pili also serve as adsorption organelles for both RNA and DNA bacteriophages. Beyond these facts, the structure, formation and function of these filaments are poorly understood. This paper describes a rapid, quantitative assay for F-pili encoded by the F plasmid type IV secretion system. The assay is based on the specific lateral adsorption of icosahedral RNA bacteriophage R17 by F-pili. Bacteriophage particles conjugated with a fluorescent dye, Alexa 488 , and bound to F-pili defined filaments visible by immunofluorescence microscopy. F-pili attached to $\mathrm{F}^{+}$cells and free F-pili were both visible by this method. For quantification, cell-bound bacteriophage were separated from free bacteriophage particles by sedimentation and released by suspending cell pellets in $0.1 \%$ SDS. Fluorescence in cell-free supernatant fractions was measured by fluorometry. The authors present a characterization of this assay and its application to F-pilus formation by cells carrying mutations in the gene for the F-pilus subunit F-pilin. Each mutation introduced a cysteine, which F-pilin normally lacks, at a different position in its primary structure. Cysteine residues in the $\mathrm{N}$-terminal domain I abolished filament formation as measured by fluorescent R17 binding. This was confirmed by measurements of DNA donor activity and filamentous DNA bacteriophage infection. With one exception (G53C), cysteines elsewhere in the F-pilin primary structure did not abolish filament formation, although some mutations differentially affected F-pilus functions.
\end{abstract}

\section{INTRODUCTION}

Conjugative pili are characteristic of type IV secretion systems that mediate horizontal gene transfer by Gramnegative bacteria (Valentine et al., 1969; Paranchych \& Frost, 1988; Ippen-Ihler \& Maneewannakul, 1991; Fullner et al., 1996; Lai \& Kado, 1998). Insofar as they have been examined, these extracellular filaments are repeats of one quantitatively predominant subunit (Paranchych \& Frost, 1988; Lai \& Kado, 1998; Eisenbrandt et al., 1999). Conjugative pili and the corresponding pilin subunits are generally identified by the origin of the type IV secretion system of which they are components. The present report concerns F-pili, which are composed of F-pilin and elaborated by $\mathrm{F}^{+}$strains of Escherichia coli.

F-pili are 8-9 $\mathrm{nm}$ in diameter and of indeterminate length. Structurally, they are hollow cylinders with a hydrophilic axial lumen that is accessible to the aqueous medium (Folkhard et al., 1979; Paranchych \& Frost, 1988; Silverman,

tPresent address: Center for Global Health and Diseases, Case Western Reserve University, Wolstein Research Building 4-4301, 10900 Euclid Avenue, Cleveland, OH 44106-7286, USA.

Abbreviations: FIU, fluorescence intensity unit(s); R17, bacteriophage R17 conjugated with Alexa 488; t.f.u., transductant-forming units.
1997). Functionally, F-pili make initial, SDS-sensitive contacts between donor and recipient cells (Achtman \& Skurray, 1977; Manning \& Achtman, 1979). Thereafter, F-pili retract so that donor and recipient cells are in direct surface-tosurface contact (Durrenberger et al., 1991). DNA transfer between closely apposed cells appears to be general (Samuels et al., 2000; Lawley et al., 2002), arguing against transfer through extended pili. In fact, once stable surface-to-surface contacts are formed, extended F-pili are no longer required for DNA transfer (Panicker \& Minkley, 1985), although a role for very short filaments cannot be excluded. F-pili also serve as adsorption organelles for several classes of bacteriophage, notably the $\mathrm{f} 2$ and $\mathrm{Q} \beta$ classes of icosahedral RNA bacteriophage and the F1/M13 class of filamentous DNA, or Ff, bacteriophage. RNA bacteriophage bind to the sides of F-pili, whereas DNA bacteriophage bind to the tip (Valentine et al., 1969).

F-pilin (70 amino acids) first accumulates as an innermembrane protein. It is derived from the $t r a A$ gene product (121 amino acids), beginning with proteolytic cleavage between TraA amino acids A51 and A52 and catalysed by host leader peptidase B (Moore et al., 1981a; Frost et al., 1984; Majdalani \& Ippen-Ihler, 1996; Majdalani et al., 1996). $N^{\alpha}$-Acetylation of A1 is required to yield 'mature' F-pilin, 
although unacetylated subunits still assemble and function (Grossman \& Silverman, 1989; Grossman et al., 1990; Moore et al., 1993; Maneewannakul et al., 1995). Unlike Tand RP4-pilins (Eisenbrandt et al., 1999), F-pilin is not circular.

Ippen-Ihler and colleagues showed that formation of membrane F-pilin requires only the traA and traQ genes (Moore et al., 1981b; Maneewannakul et al., 1993) and provided evidence that membrane F-pilin is the precursor to filament F-pilin (Sowa et al., 1983). Our studies showed that TraQ interacts directly with the C-terminal domain IV of Fpilin (Paiva et al., 1992; Harris et al., 1999), and we proposed that TraQ acts catalytically to escort TraA into the inner membrane.

Once formed, membrane F-pilin is stable as such in cells unable to elaborate F-pili (Sowa et al., 1983). F-pilus assembly from membrane F-pilin substrate requires numerous additional Tra proteins that act at or in association with the cell envelope (Firth et al., 1996; Harris et al., 2001; Harris \& Silverman, 2004). Altogether, about half the F DNA transfer (tra) genes essential for DNA transfer are required for F-pilus assembly and function (Grossman \& Silverman, 1989; Firth et al., 1996). These additional proteins form an envelope-associated secretion machine (R. Harris and others, unpublished data), as is also true of other type IV systems (Thorstenson et al., 1993; Grahn et al., 2000; Gilmour et al., 2001; Kumar et al., 2000; Krall et al., 2002).

Several indirect tests exist for the presence or absence of functional F-pili, including conjugal DNA donor activity and sensitivity to bacteriophage that use F-pili as adsorption sites. Direct assays for F-pili have included electron microscopy (Valentine et al., 1969; Curtiss et al., 1969), binding of RNA bacteriophage labelled with ${ }^{32} \mathrm{P}$ (Valentine et al., 1969), and competitive ELISA (Frost et al., 1985). The last two assays are now rarely used, electron microscopy, though poorly suited to kinetic or other studies requiring high throughput, having by default become the assay of choice for F-pili. Here we describe alternative assays that employ fluorescent bacteriophage that bind specifically to F-pili. We show that fluorescence microscopy can be used to analyse F-pili number and length distributions within and between populations, whereas fluorescence measurements can be used for rapid, quantitative assays of cell cultures. We illustrate these advantages using a set of F-pilin missense mutants.

\section{METHODS}

Strains, plasmids, bacteriophage, and culture conditions. All strains were derivatives of Escherichia coli K-12. JC3272 and JC3272/ $\mathrm{F}^{\prime}$ lac (JCFL0) have been described (Achtman et al., 1972). HfrH was originally obtained from the Coli Genetic Stock Center at Yale University. Strain AE2386 was derived from MC4100 (Casadaban, 1976). To abolish formation of type I pili, the fimD:: lac gene of strain VL386 (Freitag \& Eisenstein, 1983) was introduced into MC4100 by P1 transduction, selecting for a $\mathrm{Lac}^{+}$phenotype. This strain switched to a $\mathrm{Lac}^{-}$phenotype at high frequency and quickly became stably $\mathrm{Lac}^{-}$. A spontaneous $\mathrm{Nal}^{\mathrm{R}}$ mutant was designated AE2386. F'lac (JCFL0; Achtman et al., 1972) was introduced into AE2386 by conjugation with JC3272/F'lac, selecting for $\mathrm{Nal}^{\mathrm{R}} \mathrm{Lac}^{+}$ transconjugants. XK1200/pOX38traA::cat (Anthony et al., 1994) was obtained from Dr Laura Frost, University of Alberta, Edmonton, Canada. TOP10 [relevant markers: araD139 $\Delta($ araA-leu $)$ ] was obtained from Invitrogen and used for tightly regulated traA expression (Guzman et al., 1995). pOX38traA:: cat was introduced into TOP10 by conjugation with XK1200/pOX38traA:: cat containing pWP901, a traA $^{+}$plasmid based on the pUC19 vector backbone (W. Paiva \& P. Silverman, unpublished data). AE2248, used as a recipient in mating experiments, is a $t h r-34:: \operatorname{Tn} 10$ derivative of JC3272.

Bacteriophage R17 and the tet transducing bacteriophage F1fus2 (Parmley \& Smith, 1988) were from our laboratory stocks. R17 titres were measured by standard agar overlay with $\mathrm{HfrH}$ or JC3272/JCFL0 as host. F1fus2 titres were measured as transductant-forming units (t.f.u.) (tetracycline-resistance) with strain K91 as host (Parmley \& Smith, 1988)

Where indicated, plasmid pMR119, encoding DsRed-Express (Otto et al., 2004), was introduced by transformation.

Bacteria were grown routinely in Luria-Bertani (LB) medium supplemented with antibiotics as necessary. For bacteriophage binding, the medium was also supplemented with $10 \mathrm{mM} \mathrm{CaCl}_{2}$. Incubation was at $37^{\circ} \mathrm{C}$ with vigorous aeration. Growth was monitored by optical density at $600 \mathrm{~nm}$. When used, nutrient broth contained, per litre: $10 \mathrm{~g}$ tryptone, $1 \mathrm{~g}$ yeast extract, $8 \mathrm{~g} \mathrm{NaCl}$ and $0 \cdot 2 \%(\mathrm{w} / \mathrm{v})$ glucose.

Preparation of fluorescent R17. R17 was prepared from crude lysates by liquid polymer phase partition and isopycnic banding in step $\mathrm{CsCl}$ gradients (Yamamoto et al., 1972). After dialysis against $\mathrm{P}$ buffer $\left[50 \mathrm{mM}\right.$ TrisHCl $(\mathrm{pH} 7 \cdot 6) / 0 \cdot 1 \mathrm{M} \mathrm{NaCl} / 5 \mathrm{mM} \quad \mathrm{MgCl}_{2} /$ $0.1 \mathrm{mM}$ EDTA], the suspension was made $50 \%(\mathrm{w} / \mathrm{v})$ glycerol and stored at $-20^{\circ} \mathrm{C}$. The final titre of the preparation used in these studies was $2 \cdot 5 \times 10^{12}$ p.f.u. $\mathrm{ml}^{-1}$ and has been stable for several years.

For conjugation with fluorescent dyes, a portion of the R17 suspension (12-15 ml) was dialysed at $4{ }^{\circ} \mathrm{C}$ for $48 \mathrm{~h}$ against 2 litres of a solution containing $0 \cdot 1 \mathrm{M} \mathrm{NaHCO}(\mathrm{pH} 8 \cdot 5) / 1 \mathrm{mM} \mathrm{MgCl}_{2}$. The dialysis solution was changed once after $24 \mathrm{~h}$. Alexa 488 carboxylic acid (succinimidyl ester; Molecular Probes) $(1 \mathrm{mg}$ ) was dissolved in $0 \cdot 1 \mathrm{ml}$ anhydrous DMSO and added in $10 \mu \mathrm{l}$ aliquots to the R17 suspension with gentle stirring and at ambient temperature over a 20-30 min period. After an additional $60 \mathrm{~min}$ with gentle stirring, the R17 suspension was loaded onto two linear $\mathrm{CsCl}$ gradients $(30 \mathrm{ml}$; $\rho=1.663-1.226 \mathrm{~g} \mathrm{ml}^{-1}$ ) in P buffer. Centrifugation in the Beckman SW28 rotor was at 25000 r.p.m. for $18 \mathrm{~h}$ at $5^{\circ} \mathrm{C}$. The fluorescent band visible under UV illumination $\left(\rho \sim 1.45 \mathrm{~g} \mathrm{ml}^{-1}\right)$ was collected, dialysed against $\mathrm{P}$ buffer, diluted with an equal volume of $80 \%(\mathrm{w} / \mathrm{v})$ glycerol, and stored at $-20^{\circ} \mathrm{C}$. Titres were generally about $5 \times 10^{11}$ p.f.u. $\mathrm{ml}^{-1}$ and Alexa 488-labelling corresponded to $\sim 10^{5}$ fluorescence intensity units (FIU) $\mathrm{ml}^{-1}$. In earlier experiments, glycerol was removed by dialysis before the preparation was used, but this proved to be unnecessary.

R17 binding and fluorescence measurements. Cells $(0 \cdot 5-1 \mathrm{ml})$ and R17 (15-40 $\mu \mathrm{l})$ were mixed at $4{ }^{\circ} \mathrm{C}$ and incubated at that temperature for $10 \mathrm{~min}$. Formaldehyde ( $50 \mu \mathrm{l}$ of a $16 \%$ solution) was added and the samples incubated for $10 \mathrm{~min}$ at ambient temperature. Cells and bound bacteriophage were harvested by sedimentation for $4 \mathrm{~min}$ in a microcentrifuge at $10000 \mathrm{~g}$. Supernatant fractions were carefully removed by aspiration and discarded. Cell pellets were suspended in $1 \mathrm{ml} 0 \cdot 1 \%(\mathrm{w} / \mathrm{v})$ SDS. Cells were sedimented, suspended in $1 \mathrm{ml} 0 \cdot 1 \%$ SDS, and sedimented a last time. Supernatant fractions were combined. 
Fluorescence was measured with an excitation wavelength of $490 \mathrm{~nm}$ and an emission wavelength of $520 \mathrm{~nm}$. A blank value consisting of the fluorescence from $0 \cdot 1 \%$ SDS (40 FIU) or, depending on the experiment, from $\mathrm{F}^{-}$cells in $0 \cdot 1 \%$ SDS (50-70 FIU) was subtracted from all readings.

Fluorescence microscopy. Cells were grown to an $\mathrm{OD}_{600}$ of $0 \cdot 3-0 \cdot 4$ in Medium E salts (Vogel \& Bonner, 1956) containing $1 \%$ Casamino acids $/ 1 \%$ tryptophan $/ 1 \%$ glucose. Cultures were diluted to an $\mathrm{OD}_{600}$ of $0 \cdot 1$ with PBS and $50 \mu \mathrm{l}$ applied to a microscope dish (35 $\mathrm{mm} \times 12 \mathrm{~mm} \times 0.17 \mathrm{~mm}$; World Precision Instruments). Before use, dishes were incubated for $10 \mathrm{~min}$ in normal goat serum diluted 100-fold in PBS and then rinsed three times with PBS. After $10 \mathrm{~min}$ incubation to allow cells to adhere, excess liquid was carefully removed and replaced with $50 \mu \mathrm{l}$ R17 diluted fivefold in PBS. After $10 \mathrm{~min}$, liquid was removed and an agar disc ( $2 \%$ in PBS, $0 \cdot 16-$ $0 \cdot 19 \mathrm{~mm}$ thick) immediately placed over the cells. Fixation was with $2 \%$ formaldehyde in PBS ( $10 \mu \mathrm{l}$ added to the surface of the agarose disc). After $2 \mathrm{~min}$, excess liquid was removed and the cells were examined with a Zeiss LSM 510META laser scanning confocal microscope.

DNA donor activity and F1fus2 sensitivity. Cultures of TOP10/ pOX38traA: : cat containing traA genes cloned into a $\mathrm{pBAD}$ vector (Guzman et al., 1995) (see below) were grown to an $\mathrm{OD}_{600}$ of $0 \cdot 4$. Where appropriate, $\operatorname{traA}$ expression was induced by addition of $\mathrm{L}$ arabinose (final concentration $0 \cdot 2 \%, \mathrm{w} / \mathrm{v}$ ) $2 \cdot 5-3 \mathrm{~h}$ before the cells were used. For donor activity, $0.5 \mathrm{ml}$ of each culture was subjected to centrifugation. Supernatant fractions were aspirated and the cells suspended in $0.5 \mathrm{ml}$ of a recipient cell culture (AE2248 grown to $\mathrm{OD}_{600} 0 \cdot 23$ ). After incubation for $60 \mathrm{~min}$ at $37^{\circ} \mathrm{C}$, the cell samples were diluted and $10 \mu \mathrm{l}$ aliquots plated on media selective for transconjugants (chloramphenicol+tetracycline) and for donor cells (ampicillin + chloramphenicol).

For F1fus2 infectivity, we measured transduction of the bacteriophage tet gene. A portion $(90 \mu \mathrm{l})$ of the cultures used to measure donor activity was mixed with $10 \mu \mathrm{l}$ of an F1fus 2 preparation containing $10^{8}$ t.f.u. Samples were incubated at $4{ }^{\circ} \mathrm{C}$ for $15 \mathrm{~min}, 37^{\circ} \mathrm{C}$ for $15 \mathrm{~min}$, and subjected to centrifugation at $10000 \mathrm{~g}$ for $2 \mathrm{~min}$. Cell pellets were suspended in nutrient broth and incubated for $45 \mathrm{~min}$ at $37^{\circ} \mathrm{C}$. Portions $(10 \mu \mathrm{l})$ of serial dilutions were then spotted on $\mathrm{LB} /$ tetracycline plates.

Construction of F-pilin cysteine mutants by site-directed mutagenesis. With the exception of $\mathrm{G} 64 \mathrm{C}$, which was obtained by mutagenic PCR, cysteine mutations were introduced into traA of plasmid pWP901 using the USE Mutagenesis kit (Amersham Pharmacia Biotech). The primers used for the different mutations are listed in Table 1. We also found it necessary to introduce a third, wild-type primer for all mutations except A33C (Table 1). The reaction product was used to transform XK1200/pOX38traA::cat, selecting for $\mathrm{Cam}^{\mathrm{R}} \mathrm{Amp}^{\mathrm{R}}$ transformants. Plasmid DNA was isolated and $\operatorname{traA}$ inserts sequenced in both directions. Following Manchak et al. (2002), we transferred the mutant and wild-type traA genes into the vector $\mathrm{pBAD} / \mathrm{Myc}$-His A (Invitrogen). These plasmids were introduced by transformation into TOP10/pOX38traA:: cat.

\section{RESULTS}

\section{Binding of fluorescent R17 bacteriophage to F-pili}

Bacteriophage R17 was conjugated with the fluorescent dye Alexa 488 and purified as described in Methods. By denaturing gel electrophoresis, the R17 coat protein $(\sim 14 \mathrm{kDa}$;
Table 1. Primers used to generate F-pilin cysteine mutants

\begin{tabular}{|ll|}
\hline Primer & \multicolumn{1}{c|}{ Sequence $^{*}$} \\
\hline S4C & CATCAGGTCCTGACCACAGCTGCCGGCGG \\
G5C & CCATCAGGTCCTGACAACTGCTGCCGGC \\
S11C & CCGTGGTGTTACCGCATGCCATCAGG \\
S25C & CCATTTAACAACACAGGAGTCCTTACC \\
A33C & CGACCAGAACTTCACACAGAACAACC \\
T45C & GACGTTTTTGCACATCATGTAC \\
G53C & GATGATGGCAAAACAGGCCAGGACTTG \\
G69C & CCTGTCAGAGGCAAACGACGGCC \\
Common & CGACCAGAACTTCAGCCAGAACAACC \\
primer $\dagger$ & \\
\hline
\end{tabular}

${ }^{*}$ Cysteine codons (reverse complement) are underlined.

†Wild-type sequence corresponding to the A33C mutagenic primer.

Weber \& Konigsberg, 1975) contained essentially all of the fluorescence (Fig. 1). In addition to the coat protein, the preparation contained three other proteins visualized after Coomassie blue staining. These corresponded to $\sim 28 \mathrm{kDa}$, $\sim 37 \mathrm{kDa}$ and $\sim 48 \mathrm{kDa}$ (Fig. 1). Only the $37 \mathrm{kDa}$ protein, which corresponds in size to that of the bacteriophage A or maturation protein (Weber \& Konigsberg, 1975), contained traces of fluorescence.

Biebricher \& Duker (1984) first showed that fluorescent RNA bacteriophage bound to F-pili could be visualized by fluorescence microscopy. The result of a similar experiment but carried out with current imaging and image processing technology is shown in Fig. 2. The cells themselves, labelled internally by expression of the fluorescent protein DsRedExpress, are clearly visible. F-pili decorated with R17 showed up as fluorescent filaments in cultures of $\mathrm{tra}^{+} \mathrm{F}^{\prime}$ and $\mathrm{Hfr}$ strains but not of $\mathrm{F}^{-}$strains (not shown) or strains containing a tra mutation known to abolish F-pilus formation (Fig. 2).

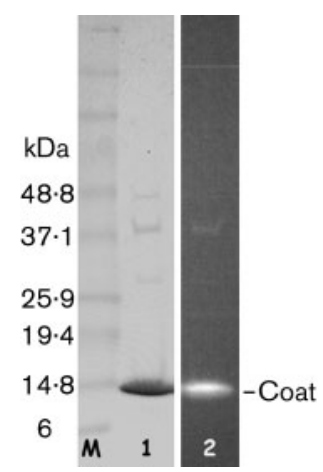

Fig. 1. Gel electrophoresis of proteins from fluorescent R17. An aliquot $(15 \mu \mathrm{l})$ of R17 conjugated with Alexa 488 as described in Methods was denatured and the proteins separated by SDS gel electrophoresis. Lane 1, Coomassie blue stain; lane 2, illuminated with UV light; lane M, size markers. 

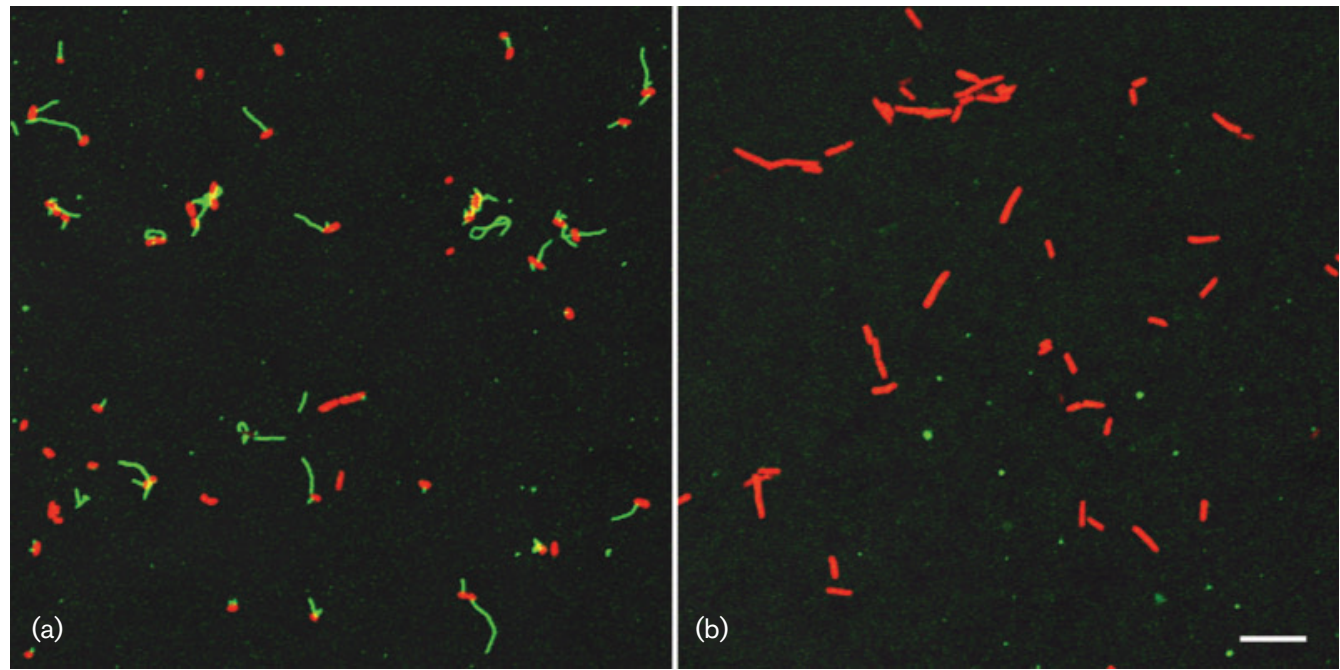

Fig. 2. Identification of F-pili by immunofluorescence microscopy of bound R17. Cells expressing DsRed-Express were cultured and prepared for microscopy as described in Methods. (a) Strain HfrH. (Substantially the same results were obtained with JC3272/F'lac.) (b) Strain JC3272/F'lac traH80. The traH80 mutation abolishes the formation of F-pili, as do mutations in any of several other tra genes (Firth et al., 1996). Examination of these other tra mutant strains yielded the same results as the traH mutant. Scale bar, $10 \mu \mathrm{m}$.

\section{Quantification of R17 binding to F-pili}

Fluorescence microscopy can quickly provide information about F-pilus number per cell and length distributions, but for some applications a quantitative, sensitive and rapid assay for total cell-attached F-pili would also be useful. We describe such an assay here.

Fluorescent R17 (2000-3000 FIU) was incubated with F'lac or isogenic $\mathrm{F}^{-}$cells $\left(0 \cdot 4-0 \cdot 7 \mathrm{OD}_{600}\right.$ units) to allow bacteriophage adsorption. Cells and bound R17 were collected by sedimentation. The pellets were suspended in $0.1 \%$ SDS, which dissolves F-pili but leaves cells intact. Cells were removed by sedimentation and washed once with SDS. Fluorescence of the combined supernatant fractions was then measured. In preliminary assays, fluorescence in supernatant fractions from $\mathrm{F}^{\prime}$ or $\mathrm{Hfr}$ cells corresponded to 500-800 FIU per OD $_{600}$ unit, depending on the strain. Fluorescence in equivalent fractions from $\mathrm{F}^{-}$cells was 50 70 FIU per $\mathrm{OD}_{600}$ unit. Fluorescence increased linearly with increasing amounts of $\mathrm{F}^{+}$cells except at very low levels $\left(<0 \cdot 1 \mathrm{OD}_{600}\right.$ unit) (Fig. 3) and it was proportional to culture density during exponential growth (Fig. 4). As the culture left exponential growth $\left(\mathrm{OD}_{600}>1 \cdot 5\right)$, the ratio FIU/ $\mathrm{OD}_{600}$ unit began to diminish (Fig. 4); a stationary-phase culture of the $\mathrm{F}^{\prime}$ lac strain used in this experiment $\left(\mathrm{OD}_{600}\right.$ 3.2) measured 450 FIU per $\mathrm{OD}_{600}$ unit. This reduced level of F-piliation undoubtedly reflects the well-established $\mathrm{F}^{-}$ phenocopy effect.

\section{Induction of traA assayed by R17 binding}

Rapidity and sensitivity, the two main advantages of the fluorescence assay described above, are especially useful for kinetic experiments. An example is the formation of F-pili after $\operatorname{tra} A$ induction. We first constructed a plasmid in which the traA gene was expressed from the araBAD promoter (see Methods). This construct was introduced into TOP10/pOX38traA : : cat cells. A culture was then induced by addition of arabinose $(0 \cdot 2 \%)$, and R17 binding was followed as functions of time and culture density. An uninduced culture served as a control. R17 binding could be

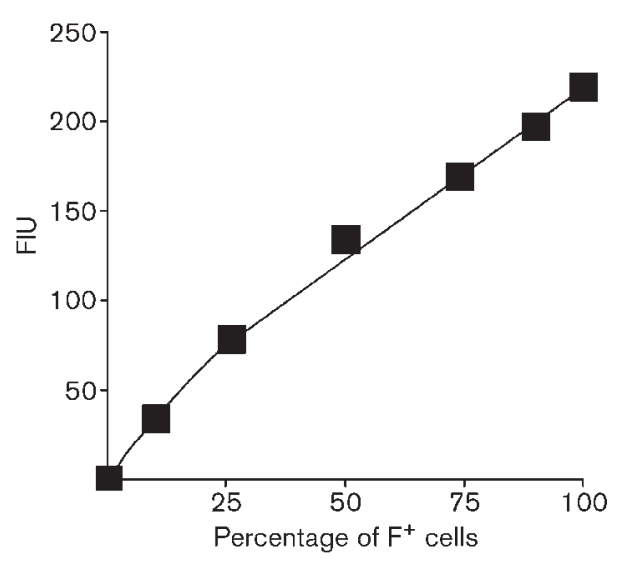

Fig. 3. Quantitative $R 17$ binding as a function of the $F^{+} / F^{-}$ cell ratio. $F^{-}$strain $A E 2386$ and $F^{+}$strain $A E 2386 / F^{\prime}$ lac were grown to $\mathrm{OD}_{600}$ values of 0.86 and $0 \cdot 70$, respectively. Mixtures contained the amounts of the $\mathrm{F}^{+}$strain indicated and amounts of the $\mathrm{F}^{-}$strain to yield a total of $0.4 \mathrm{OD}_{600}$ units per sample. R17 binding was then measured as described in Methods. This experiment was repeated three times and reproducibly showed non-linearity below about $0 \cdot 1 \mathrm{OD}_{600}$ units of $\mathrm{F}^{+}$cells. 


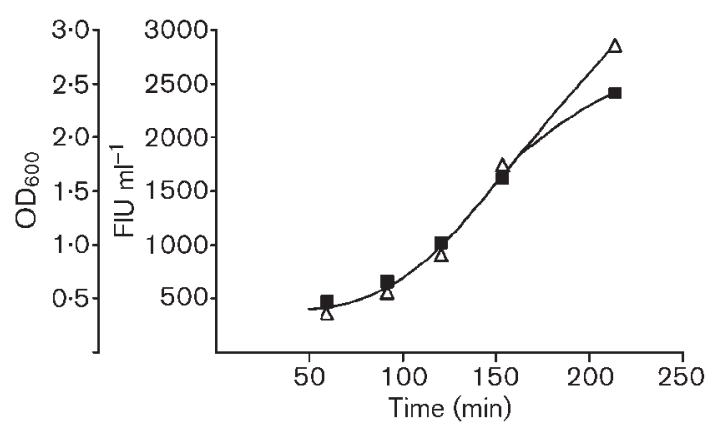

Fig. 4. F-piliation as a function of culture density. AE2386/ $\mathrm{F}^{\prime}$ lac was grown in LB medium at $37^{\circ} \mathrm{C}$ with aeration. Portions of the culture at the indicated times were assayed for R17 binding $(\square)$ and $\mathrm{OD}_{600}(\triangle)$.

observed in the induced culture within $60 \mathrm{~min}$ of arabinose addition and reached a maximum specific activity (FIU per $\mathrm{OD}_{600}$ unit) after 3-4 h (Fig. 5a). In contrast, no binding above background was observed with uninduced cells (Fig. 5a). Note also that traA induction in these conditions drastically curtailed growth (Fig. 5b), an effect probably related to F-pilin overexpression.
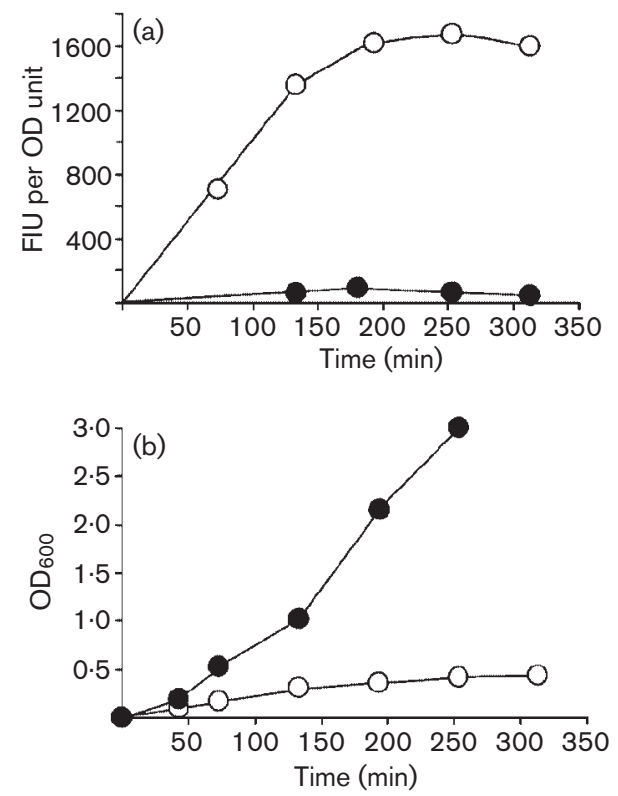

Fig. 5. F-pili as a function of time after $\operatorname{tra} A$ induction. Strain TOP10 containing pOX38 traA::cam and pBADtraA ${ }^{+}$was incubated with aeration from a starting $\mathrm{OD}_{600}$ of 0.02 for $45 \mathrm{~min}$. To one culture, arabinose was added to $0.1 \%$; a second culture served as uninduced control. At the indicated times, samples were removed for measurement of F-pili by R17 binding (a) and culture density (b). ๑, No arabinose added; $\bigcirc$, arabinose added.

\section{Cysteine-containing F-pilin mutants}

Similar to studies by Manchak et al. (2002), we have been constructing and characterizing F-pilin missense mutants, in conjunction with structural studies of F-pili necessary to interpret their effects. Here, we use a subset of such mutants to illustrate the utility and one limitation of the methods described above.

F-pilin, which is only 70 amino acids in length, normally lacks cysteines (Frost et al., 1984). We constructed several mutant $\operatorname{tra} A$ genes, each with a cysteine codon at a different site (Table 2). Four of the mutations were in domain I, one in domain II, one in domain III and three in domain IV (Table 2) (Paiva et al., 1992). (Note that the traAS25C gene also contained a second mutation, A55V.) These mutant traA genes were cloned into a $\mathrm{PBAD}$ vector as described in Methods.

All of the mutants accumulated high levels of membrane F-pilin (Fig. 6). Accumulation was dependent on arabinose induction (Fig. 6, lanes 1 and 2). The S4C and G5C mutants appear to accumulate less than the others (Fig. 6, lanes 3 and 4), but we attribute this to the fact that these mutations are within the wild-type sequence used to raise the anti-peptide antibody used in these experiments (Paiva et al., 1992) and hence have altered epitopes.

Even though these mutant F-pilins accumulated to normal or nearly normal levels, not all formed F-pili. Of the nine mutants tested, only three were positive by R17 binding and only one mutant, containing the G64C mutation, supported as much R17 binding as the wild-type control (Table 2). Tests based on conjugal DNA donor activity and filamentous bacteriophage F1fus2 sensitivity largely confirmed these results (Table 2). Two mutations, A33C and T45C, led to significantly reduced R17 binding; fluorescence microscopy showed that both these mutations, but especially T45C, led to shorter-than-normal filaments (data not shown). Short filaments would not be expected to affect functions, such as $\mathrm{Ff}$ phage binding, that require only an F-pilus 'tip', and both the A33C and T45C mutants remained sensitive to F1fus2 and active as DNA donors (Table 2). One mutation, G69C, abolished R17 binding without affecting DNA donor activity or F1fus2 sensitivity (Table 2). This mutation appears to have specifically altered R17 adsorption sites along the F-pilus side.

\section{DISCUSSION}

Notwithstanding the essential role of conjugative pili in horizontal DNA transfer mediated by type IV secretion systems, their structure, function and assembly are not well understood. The work we describe here was undertaken as part of a broader effort to determine how F-pili are formed and how they function. We were interested in developing simple assays that would yield a statistical profile of F-pili in bacterial populations (F-pilus number per cell and length distributions) and allow for comparative studies of total 
Table 2. Structure and functions of F-pilin cysteine mutants

Functional measurements were as described in Methods.

\begin{tabular}{|c|c|c|c|}
\hline \multirow[t]{2}{*}{ Mutation } & Sequence $^{*}$ & \multirow{2}{*}{$\begin{array}{c}\text { R17 } \\
\text { binding } \\
\text { (FIU per } \\
\left.\text { OD }_{600} \text { unit }\right)\end{array}$} & \multirow{2}{*}{$\begin{array}{l}\text { DNA donor } \\
\text { activity, } \\
\text { F1fus2 } \\
\text { sensitivity }\end{array}$} \\
\hline & Domain I $\longleftrightarrow$ II $\longrightarrow$ III $\longleftrightarrow$ IV & & \\
\hline None & AGSSGQDLMASGNTTVKATFGKDSSVVKWVVLAEVLVGAVMYMMTKNVKFLAGFAI ISVFIAVGMAVVGL & 600 &,++ \\
\hline S4C & AGSCGGDLMASGNTTVKATFGKDSSVVKWVVLAEVLVGAVMYMMTKNVKFLAGFA I SVFIAVGMAVVGL & $<10$ &,-- \\
\hline G5C & AGSSCEDLMASGNTTVKATFGKDSSVVKWVVLAEVLVGAVMYMMTKNVKFLAGFAI ISVFIAVGMAVVGL & $<10$ &,-- \\
\hline S11C & AGSSGQDLMACGNTTVKATFGKDSSVVKWVVLAEVLVGAVMYMMTKNVKFLAGFAI I SVFIAVGMAVVGL & $<10$ &,-- \\
\hline S25C & AGSSGQDLMASGNTTVKATFGKDSCEVVKWVVLAEVLVGAVMYMMTKNVKFLAGF $\underline{\mathbf{V} I ~ I S V F I A V G M A V V G L ~}$ & $<10$ &,-- \\
\hline A33C & AGSSGQDLMASGNTTVKATFGKDSSVVKWVVLCEVLVGAVMYMMTKNVKFLAGFAI ISVFIAVGMAVVGL & 81 &,++ \\
\hline $\mathrm{T} 45 \mathrm{C}$ & AGSSGQDLMASGNTTVKATFGKDSSVVKWVVLAEVLVGAVMYMMCKNVKFLAGFAI ISVFIAVGMAVVGL & 39 &,++ \\
\hline G53C & AGSSGQDLMASGNTTVKATFGKDSSVVKWVVLAEVLVGAVMYMMTKNVKFLACCFAI ISVFIAVGMAVVGL & $<10$ &,-- \\
\hline G64C & AGSSGQDLMASGNTTVKATFGKDSSVVKWVVLAEVLVGAVMYMMTKNVKFLAGFA I ISVFIAVC̣MAVVGL & 400 &,++ \\
\hline G69C & AGSSGQDLMASGNTTVKATFGKDSSVVKWVVLAEVLVGAVMYMMTKNVKFLAGFA I ISVF IAVGMAVVĆL & $<10$ &,++ \\
\hline
\end{tabular}

${ }^{\star}$ Domain designations I-IV were as described by Paiva et al. (1992).

F-pilus levels in different cell populations or in the same population at different times or after different physiological perturbations. The main advantage of the fluorescence assays we describe here over previous assays (Valentine et al., 1969; Curtiss et al., 1969; Frost et al., 1985) is that all the information can be obtained with only a single reagent. Fluorescent $\mathrm{R} 17$ is straightforward and inexpensive to prepare and stable for years, unlike bacteriophage containing $\left[{ }^{32} \mathrm{P}\right] \mathrm{RNA}$ used in filter binding assays. Sample preparation for fluorescence microscopy is certainly no more time consuming or complicated than that for negative staining and electron microscopy, and a single field can yield data on scores of cells.

As with other assays for F-pili, the ones we describe here rely on the lateral binding of RNA bacteriophage to F-pili. This can be misleading. As we have shown here for the G69C

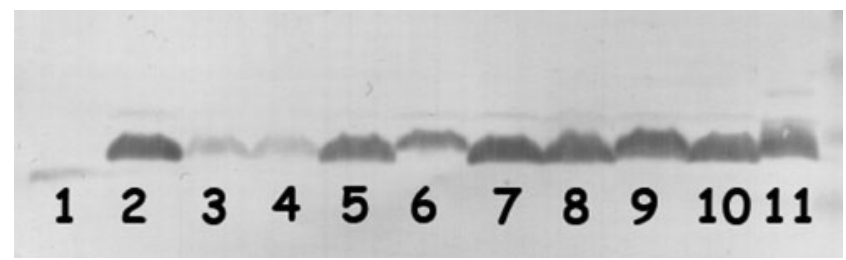

Fig. 6. Accumulation of F-pilin cysteine mutants. TOP10/ pOX38traA::cam containing pBAD derivatives of $\operatorname{tra}^{+}$(see Fig. 5) or each of the cysteine mutants shown in Table 2 were induced as described in the legend to Fig. 5. The same amount of each culture $\left(0.5 \mathrm{OD}_{600}\right.$ units) was used to analyse F-pilin levels by Western blotting as described by Paiva et al. (1992), except that we used Immobilon PSQ medium for transfer. Lane 1, $\mathrm{pBADtra} A^{+}$, uninduced; lane 2, $\mathrm{pBADtra} A^{+}$, induced; lanes 3-11: pBAD traA mutants S4C, G5C, S11C, S25C, A33C, T45C, G53C, G64C and G69C, respectively.
F-pilin mutant, and as Grossman \& Silverman (1989) and Manchak et al. (2002) have also shown, altered F-pilins can be incorporated into filaments that fail to bind RNA bacteriophage. Such ambiguities might be minimized by using cysteine-reactive fluorescent dyes, rather than fluorescent bacteriophage, in conjunction with cysteine-containing F-pili.

Manchak et al. (2002), examining the effects of single missense mutations of F-pilin, found that in general DNA donor activity and sensitivity to filamentous DNA bacteriophage tracked together. In contrast, several mutations abolished RNA bacteriophage sensitivity with less of an effect on the other two functions. The G69C mutation we describe here evidently belongs in this class. The effects of the G69C mutation can not be attributed to the presence of cysteine at this locus since the G69D mutation had much the same effects (Frost \& Paranchych, 1988). Interestingly, neither we nor Manchak et al. (2002), nor the more limited study by Frost \& Paranchych (1988), identified F-pilin missense mutants that significantly reduced Ff bacteriophage sensitivity and DNA donor activity without also reducing or abolishing RNA bacteriophage sensitivity. One explanation for these data is that donor activity and DNA bacteriophage sensitivity are relatively robust functions with respect to modest alterations to F-pilin structure, whereas RNA bacteriophage infection is more sensitive.

\section{ACKNOWLEDGEMENTS}

K. D. acknowledges the encouragement and support provided by Professor Dr med. Uwe Gross at Georg-August-Universität, Göttingen, Germany. We acknowledge the contributions to this work of the facilities and expertise of the Imaging Core Facility at the Oklahoma Medical Research Foundation. This work was supported at the Oklahoma Medical Research Foundation by NSF grant MCB-0212365 
to P.M.S. and by the Studienstiftung des deutschen Volkes to K. D. P.M.S. acknowledges support from the Marjorie Nichlos Chair in Medical Research.

\section{REFERENCES}

Achtman, M. \& Skurray, R. (1977). A redefinition of the mating phenomenon in bacteria. In Microbial Interactions, pp. 234-279. Edited by J. Reissig. London: Chapman \& Hall.

Achtman, M., Willetts, N. \& Clark, J. (1972). Beginning a genetic analysis of conjugational transfer determined by the $\mathrm{F}$ factor in Escherichia coli by isolation and characterization of transfer-deficient mutants. J Bacteriol 106, 529-538.

Anthony, K., Sherburne, C., Sherburne, R. \& Frost, L. (1994). The role of the pilus in recipient cell recognition during bacterial conjugation mediated by F-like plasmids. Mol Microbiol 13, 939-953.

Biebricher, C. \& Duker, E.-M. (1984). Light-microscopic visualization of F and type 1 pili. J Gen Microbiol 130, 941-949.

Casadaban, M. (1976). Regulation of the regulatory gene for the arabinose pathway, araC. J Mol Biol 104, 557-566.

Curtiss, R., Caro, L., Allison, D. \& Stallions, D. (1969). Early stages of conjugation in Escherichia coli. J Bacteriol 100, 1091-1104.

Durrenberger, M., Villiger, W. \& Bachi, Th. (1991). Conjugational junctions: morphology of specific contacts in conjugating Escherichia coli bacteria. J Struct Biol 107, 146-156.

Eisenbrandt, R., Kalkum, M., Lai, E., Lurz, R., Kado, C. \& Lanka, E. (1999). Conjugative pili of IncP plasmids, and the Ti plasmid T pilus are composed of cyclic subunits. J Biol Chem 274, 22548-22555.

Firth, N., Ippen-Ihler, K. \& Skurray, R. (1996). Structure and function of the F factor and mechanism of conjugation. In Escherichia coli and Salmonella, Cellular and Molecular Biology, pp. 2377-2401. Edited by F. C. Neidhardt and others. Washington, DC: American Society for Microbiology.

Folkhard, W., Leonard, K., Malsey, S., Marvin, D., Dubochet, J., Engel, A., Achtman, M. \& Helmuth, R. (1979). X-ray diffraction and electron microscope studies on the structure of F pili. J Mol Biol 130, 145-160.

Freitag, C. \& Eisenstein, B. (1983). Genetic mapping and transcriptional orientation of the fimD gene. J Bacteriol 156, 1052-1058.

Frost, L. \& Paranchych, W. (1988). DNA sequence analysis of point mutations in traA, the F-pilin gene, reveal two domains involved in F-specific phage attachment. Mol Gen Genet 213, 134-139.

Frost, L., Paranchych, W. \& Willetts, N. (1984). DNA sequence of the F traALE region that includes the gene for F-pilin. J Bacteriol 160, 395-401.

Frost, L., Finlay, B., Opgenorth, A., Paranchych, W. \& Lee, J. (1985). Characterization and sequence analysis of pilin from F-like plasmids. J Bacteriol 164, 1238-1247.

Fullner, K., Lara, J. \& Nester, E. (1996). Pilus assembly by Agrobacterium T DNA genes. Science 273, 1107-1109.

Gilmour, M., Lawley, T., Rooker, M., Newnham, P. \& Taylor, D. (2001). Cellular location and temperature-dependent assembly of IncH1 plasmid R27-encoded TrhC-associated conjugative transport protein complexes. Mol Microbiol 42, 705-715.

Grahn, A., Haase, J., Bamford, D. \& Lanka, E. (2000). Components of the RP4 conjugative transfer apparatus form an envelope structure bridging inner and outer membranes of donor cells, implications for related macromolecular transport systems. J Bacteriol 182, $1564-1574$.
Grossman, T. \& Silverman, P. (1989). Structure and function of conjugative pili, inducible synthesis of functional F-pili by Escherichia coli K12 containing a lac-tra operon fusion. J Bacteriol 171, 650-656.

Grossman, T., Frost, L. \& Silverman, P. (1990). Structure and function of conjugative pili: monoclonal antibodies as probes for structural variants of F-pili. J Bacteriol 172, 1174-1179.

Guzman, L.-M., Belin, D., Carson, M. \& Beckwith, J. (1995). Tight regulation, modulation, and high-level expression by vectors containing the arabinose pBAD promoter. J Bacteriol 177, 4121-4130.

Harris, R. L. \& Silverman, P. M. (2004). Tra proteins characteristic of F-like Type IV secretion systems constitute an interaction group by yeast two-hybrid analysis. J Bacteriol 186, 5480-5485.

Harris, R., Sholl, A., Conrad, M., Dresser, M. \& Silverman, P. (1999). Interaction between the F plasmid TraA (F-pilin) and TraQ proteins. Mol Microbiol 34, 780-791.

Harris, R., Hombs, V. \& Silverman, P. (2001). Evidence that F-plasmid proteins TraV, TraK, and TraB assemble into an envelopespanning structure in Escherichia coli. Mol Microbiol 42, 757-766.

Ippen-Ihler, K. \& Maneewannakul, S. (1991). Conjugation among enteric bacteria: mating systems dependent on expression of pili. In Microbial Cell-Cell Interactions, pp. 35-69. Edited by M. Dworkin. Washington, DC: American Society for Microbiology.

Krall, L., Wiedemann, U., Unsin, G., Weiss, S., Domke, N. \& Baron, C. (2002). Detergent extraction identifies different VirB protein subassemblies of the type IV secretion machinery in the membranes of Agrobacterium tumefaciens. Proc Natl Acad Sci U S A 99, 1140511410.

Kumar, R., Xie, Y.-H. \& Das, A. (2000). Subcellular localization of the Agrobacterium tumefaciens T-DNA transport pore proteins: VirB8 is essential for the assembly of the transport pore. Mol Microbiol 36, 608-617.

Lai, E.-M. \& Kado, C. (1998). Processed VirB2 is the major subunit of the promiscuous pilus of Agrobacterium tumefaciens. J Bacteriol 180, 2711-2717.

Lawley, T., Gordon, G., Wright, A. \& Taylor, D. (2002). Bacterial conjugative transfer: visualization of successful mating pairs and plasmid establishment in live Escherichia coli. Mol Microbiol 44, 947-956.

Majdalani, N. \& Ippen-Ihler, K. (1996). Membrane insertion of the F-pilin subunit is Sec independent but requires leader peptidase B and the proton motive force. J Bacteriol 178, 3742-3747.

Majdalani, N., Moore, D., Maneewannakul, S. \& Ippen-Ihler, K. (1996). Role of the propilin leader peptide in the maturation of F-pilin. J Bacteriol 178, 3748-3754.

Manchak, J., Anthony, K. \& Frost, L. (2002). Mutational analysis of F-pilin reveals domains for pilus assembly, phage infection, and DNA transfer. Mol Microbiol 43, 195-205.

Maneewannakul, K., Maneewannakul, S. \& Ippen-Ihler, K. (1993). Synthesis of F-pilin. J Bacteriol 175, 1384-1391.

Maneewannakul, K., Maneewannakul, S. \& Ippen-Ihler, K. (1995). Characterization of traX, the $\mathrm{F}$ plasmid locus required for acetylation of F-pilin subunits. J Bacteriol 177, 2957-2964.

Manning, P. \& Achtman, M. (1979). Cell-to-cell interactions in conjugating Escherichia coli: the involvement of the cell envelope. In Bacterial Outer Membranes, pp. 409-448. Edited by M. Inouye. New York: Wiley Interscience.

Moore, D., Sowa, B. \& Ippen-Ihler, K. (1981a). Location of an F-pilin pool in the inner membrane. J Bacteriol 146, 251-259.

Moore, D., Sowa, B. \& Ippen-Ihler, K. (1981b). The effect of tra mutations on the F-pilin polypeptide. Mol Gen Genet 184, 260-264. 
Moore, D., Hamilton, C., Maneewannakul, K., Mintz, Y., Frost, L. \& Ippen-Ihler, K. (1993). The Escherichia coli K-12 F plasmid gene traX is required for acetylation of F-pilin. J Bacteriol 175, 1375-1383.

Otto, G., Wu, M., Clarke, M., Lu, H., Anderson, O., Hilbi, H., Shuman, H. \& Kessin, R. (2004). Autophagy is dispensable for intracellular replication of Legionella pneumophila in Dictyostelium discoideum. Mol Microbiol 51, 63-72.

Paiva, W., Grossman, T. \& Silverman, P. (1992). Characterization of F-pilin as an inner membrane component of Escherichia coli K12. J Biol Chem 267, 26191-26197.

Panicker, M. \& Minkley, E., Jr (1985). DNA transfer occurs during a cell surface contact stage of $\mathrm{F}$ sex factor-mediated bacterial conjugation. J Bacteriol 162, 584-590.

Paranchych, W. \& Frost, L. (1988). The physiology and biochemistry of pili. Adv Microb Physiol 29, 53-114.

Parmley, S. \& Smith, G. (1988). Antibody-selectable filamentous fd phage vectors: affinity purification of target genes. Gene 73, 305-318.

Samuels, A., Lanka, E. \& Davies, J. (2000). Conjugative junctions in RP-4-mediated mating of Escherichia coli. J Bacteriol 182, 2709-2715.
Silverman, P. (1997). Towards a structural biology of bacterial conjugation. Mol Microbiol 23, 423-429.

Sowa, B., Moore, D. \& Ippen-Ihler, K. (1983). Physiology of F-pilin synthesis and utilization. J Bacteriol 153, 962-968.

Thorstenson, Y., Kuldau, G. \& Zambryski, P. (1993). Subcellular localization of seven VirB proteins of Agrobacterium tumefaciens: implications for the formation of a T-DNA transport structure. J Bacteriol 175, 5233-5241.

Valentine, R., Silverman, P., Ippen, K. \& Mobach, H. (1969). The F-pilus of Escherichia coli. Adv Microb Physiol 3, 1-52.

Vogel, H. \& Bonner, D. (1956). Acetylornithinase of Escherichia coli: partial purification and some properties. J Biol Chem 218, 97-106.

Weber, K. \& Konigsberg, W. (1975). Proteins of RNA phages. In RNA Phages, pp. 51-84. Edited by N. D. Zinder. Cold Spring Harbor, NY: Cold Spring Harbor Laboratory.

Yamamoto, K., Alberts, B., Benziger, R., Lawhorne, L. \& Treiber, G. (1972). Rapid bacteriophage sedimentation in the presence of polyethylene glycol and its application to large-scale virus purification. Virology 40, 734-744. 